$10-2016$

\title{
Book Review: Conflict in the Nuba Mountains: From Genocide-by- Attrition to the Contemporary Crisis in Sudan
}

Alan J. Kuperman

University of Texas at Austin

Follow this and additional works at: https://digitalcommons.usf.edu/gsp

\section{Recommended Citation}

Kuperman, Alan J. (2016) "Book Review: Conflict in the Nuba Mountains: From Genocide-by-Attrition to the Contemporary Crisis in Sudan," Genocide Studies and Prevention: An International Journal: Vol. 10: Iss. 2: 131-134.

DOI:

http://dx.doi.org/10.5038/1911-9933.10.2.1415

Available at: https://digitalcommons.usf.edu/gsp/vol10/iss2/11

This Book Review is brought to you for free and open access by the Open Access Journals at Digital Commons @ University of South Florida. It has been accepted for inclusion in Genocide Studies and Prevention: An International Journal by an authorized editor of Digital Commons @ University of South Florida. For more information, please contact digitalcommons@usf.edu. 


\title{
Book Review: Conflict in the Nuba Mountains: From Genocide-by-Attrition to the Contemporary Crisis in Sudan
}

\author{
Alan J. Kuperman \\ LBJ School of Public Affairs, University of Texas at Austin \\ Austin, TX, USA
}

Conflict in the Nuba Mountains: From Genocide-by-Attrition to the Contemporary Crisis in Sudan

Samuel Totten and Amanda Grzyb, editors

New York, Routledge, 2014

314 Pages; Price: \$140.00 Cloth, \$47.95 Paperback

Reviewed by Alan J. Kuperman

LBJ School of Public Affairs, University of Texas at Austin

This is an important book about a deadly conflict that has been overshadowed by higherprofile violence in neighboring Darfur and South Sudan. Although somewhat biased in favor of the rebels who claim to represent the main victims in the conflict, the book includes several more balanced chapters that allow a careful reader to gain a better understanding. The only thing missing, regrettably, is the government's side of the story, which would have facilitated a holistic perspective.

The book's underlying thesis - conveyed most clearly in two chapters, one by Rebecca Tinsley and the other by the book's co-editor, Samuel Totten - is that impunity perpetuates atrocity. In the early 1990s, according to the book, Sudan's emerging Islamist regime perpetrated genocide against the Nuba people of South Kordofan. When the regime suffered no punishment, it was emboldened to replicate that violence in Darfur a decade later. When that crime too went unpunished, the regime was emboldened to resume genocide against the Nuba the following decade. It is a clear thesis. Less clear is whether the facts support it, especially with regard to the most recent violence in the Nuba Mountains, as elaborated below.

What is indisputable and amply documented in the book's opening chapters is that the Nuba people-a catch-all name for the Black Africans who live in the Nuba Mountains and share some cultural attributes but speak dozens of different languages - have suffered terribly for a long time. In centuries past they were captured and enslaved. Under British rule, they were isolated from modernization. After independence, their fertile land was seized by well-connected Sudanese elite for large agricultural projects, forcing them to retreat into the mountains. Seasonally, the sedentary Nuba farmers also faced competition for land with migratory Arab pastoralists seeking to graze their herds.

Violence reached new heights in the context of Sudan's second north-south civil war that started in 1983. The Nuba lived just north of the historical internal border but shared grievances with the southerners regarding neglect and discrimination by the Khartoum elite. In 1987, some of these Nuba welcomed a commander from the southern Sudan People's Liberation Army (SPLA) to launch a northern front in the rebellion against Khartoum. The Nuba thereby became a Fifth Column in the southern rebels' war against the north, and accordingly soon suffered the punishment that often falls upon suspected domestic accomplices of the enemy during wartime.

The book makes a strong case that the Sudanese government's retaliatory violence against the Nuba escalated to genocidal levels in the early 1990s due to the ethnoreligious fervor of the Islamist regime that seized power in Khartoum in 1989. As J. Millard Burr, Guma Kunda Komey, and Alex de Waal explain in their respective chapters, Jihad was declared against the Nuba people, including its Muslim majority that was characterized as apostate. The regime also attempted to modify the region's demographics by forcibly relocating tens of thousands of Nuba to "peace villages," a process that involved segregating the women and subjecting them to sexual violence by Arab forces. The resulting death toll is disputed in several of the book's chapters, but may have been in the range of 100,000, about ten percent of the Nuba population at the time.

That round of violence in the Nuba Mountains ended in the context of negotiations over the north-south war, culminating in the Comprehensive Peace Agreement (CPA) of 2005, which offered the south a secession referendum in 2011. Several of the book's contributors- 
Mudawi Ibrahim Adam, Alex de Waal, and Jok Madut Jok-contend that the SPLM effectively double-crossed its Nuba allies, initially using them as a stalking horse for leverage against Khartoum, and then signing a peace deal that abandoned them to the north. SPLM leader John Garang personally supported staying in a reformed Sudan, but after he died in a helicopter crash in 2005, the south increasingly embraced secession, leaving the Nuba with little to show for their years of fighting and suffering. Under the CPA, South Kordofan would not hold a referendum but only a "popular consultation" within four years so that its legislature could assess the CPA, but even this modest procedure never was implemented.

The CPA also called for democratic elections in South Kordofan, which eventually were held a year late in May 2011. The book's most fascinating details - in chapters by John Young and Siddig Kafi - reveal the local politics behind this vote and thereby shed light on its consequences too. The gubernatorial battle pitted two notorious military commanders. The regime's candidate was Ahmed Haroun, who had led government troops against the Nuba in the 1990s and then oversaw the brutal counterinsurgency in Darfur in the 2000s. The candidate of the SPLMNorth (SPLM-N) - as the party was renamed in Sudan following the south's secession-was Abdelaziz al-Hilu. He had helped launch an ill-fated rebellion in Darfur 1991 and then, as deputy commander of the Nuba rebels, was accused of targeting civilians.

As Young documents, the regime candidate won the election narrowly, according to all three relevant authorities: the national election commission, the domestic observation mission, and the international observation mission of The Carter Center. The SPLM-N's al-Hilu, however, rejected that outcome and resumed a war footing. The regime then issued an ultimatum for his forces to disarm or depart for South Sudan, as envisioned under the CPA. When al-Hilu refused, the government forcibly attempted to disarm his troops in June 2011, triggering a new war in South Kordofan, which soon spread to Blue Nile state. Fighting in these "Two Areas" has continued until the time of this writing in July 2016. According to Young, it was the SPLM-N's original refusal to accept its electoral loss that "set the Nuba Mountains on a course of war."

Western critics of Sudan's regime, by contrast, claim that it stole the election and thus is to blame for the resumption of fighting. However, several of the book's chapters explain how and why the SPLM-N actually did lose, thus casting a very different light on the party's refusal to accept that outcome, and on the resulting violence. As Mudawi Ibrahim Adam reports in his chapter, "The Dilemma of the Nuba," the SPLM-N in South Kordofan often acted as an exclusively Nuba party, which alienated other ethnic groups that otherwise disliked the regime and might have supported the SPLM-N. Another factor undercutting SPLM-N support, as detailed by both Siddig T. Kafi and John Young, is that the Nuba themselves were divided, and many of them resented the domination of the SPLM-N and al-Hilu, whose roots lay outside South Kordofan. One Nuba commander, Gen. Talafon Kuku, actually ran against al-Hilu - upon which the SPLM imprisoned him in South Sudan - while another northern Nuba commander (Gen. Ismail Khamis Jallab) dissociated himself from the SPLM-N.

As a longstanding senior commander of the SPLA, al-Hilu favored the secession of both South Sudan and Abyei from Sudan, but these stances proved unpopular in the western part of South Kordofan and even among many Nuba who stood to become more isolated and vulnerable in a rump Sudan, as detailed by Young in his chapter on "South Kordofan State Elections, May 2011." Many Nuba also distrusted al-Hilu for having cooperated with the regime as deputy governor under the CPA from 2009-2011, even though living conditions improved during that time. Finally, the regime deftly engaged in coalition politics, courting traditional Sudanese parties in South Kordofan, while the SPLA alienated them by refusing to pledge a coalition government. All these missteps help explain how and why al-Hilu managed to lose an election to Haroun, a candidate who had been indicted by the International Criminal Court (ICC) for war crimes in Darfur.

Several of the book's chapters regrettably stretch the truth by not only blaming the regime for the resumption of war but also accusing it of an extermination campaign. Jok Madut Jok, for example, asserts that the "genocidal actions of the 1990s have been unleashed once again, and the survival of the Nuba people hangs in the balance" (160). Gillian Lusk similarly contends that the regime is driven by an annihilationist agenda akin to that of al Qaeda or ISIS. Thankfully, Young's 
chapter exposes such hyperbole, criticizing Lusk's analysis as marred by "a visceral hatred of the [regime] and failure to acknowledge SPLM failings" (174).

There is enough blame to go around. The SPLM-N is guilty of refusing to accept its loss in the 2011 democratic elections, which sparked the renewal of war. But the regime might well have done the same if it had lost. During the campaign, Sudan's President Omar Bashir declared that the regime would win "either by ballot boxes or bullet boxes" (217). This mirrored the SPLM-N's threatening campaign rhetoric that announced voters had a choice between "the star [its party's flag] or the gun" (171). In light of such signaling by both sides of unwillingness to accept possible electoral loss, the resumption of war may have been inevitable.

Regrettably several contributors - especially Jok, Lusk, Tinsley, and Totten-blame the regime alone for the ongoing humanitarian deprivation in the Nuba Mountains. The Khartoum government does bear some responsibility, as it has blocked international NGOs from entering rebel-held territory via Sudan, on grounds that such organizations in the past have aided Sudanese rebels and assisted international prosecution of regime officials. At the same time, however, the SPLM-N has rejected repeated regime offers of a temporary cease-fire to enable neutral international actors to deliver humanitarian aid and administer vaccines in rebel-controlled areas. Apparently, the rebels fear that an informal humanitarian cease-fire could reflect well on the regime and undermine their negotiating leverage. The SPLM-N thus also bears some responsibility for perpetuating the suffering of its own Nuba civilians.

In several places, the book exaggerates the suffering of Nuba civilians by denying the existence of an aid pipeline. For example, Totten writes that as of April 2014, "no such humanitarian corridor has been established" (129). To the contrary, in spring 2012, the United States initiated regular shipments of humanitarian aid by an international NGO via South Sudan to hundreds of thousands in South Kordofan, as U.S. and SPLM-N officials have confirmed in published accounts.

Several of the book's contributors also mischaracterize the regime's aerial bombing as targeting civilians. Totten, for example, cites "almost daily bombings by Antonovs of civilian targets (suqs, churches, villages, farms, and other places where relatively sizeable groups of people congregated)" 129). In reality, most of the government's bombing has targeted rebels or sparsely populated areas. As Wendy James notes in her chapter on the parallel war in Blue Nile state, such targeting of rebels has succeeded in forcing them to retreat to the border region near South Sudan. When the government has targeted supposedly "civilian" areas, she writes, those are "where the SPLA-N was indeed holding out" (205).

During the first three years of renewed war in South Kordofan-according to data compiled by the anti-government Sudan Consortium that is not cited in the book-aerial bombing killed approximately one non-combatant per week, a relatively modest rate that is not indicative of targeting congregated civilians. Indeed, the combined military and civilian death toll from war in the Two Areas since 2011 is estimated at only hundreds per year (see, for example, the U.S. State Department Human Rights Reports for Sudan in 2012 and 2013). While any war death is tragic, such statistics suggest that the nature of violence is quite different from the allegedly genocidal campaigns of the early 1990s.

Cogently, a few of the book's contributors interrogate the actual aim of the rebellion. The people of the Nuba Mountains clearly have legitimate grievances. For example, as Komey delineates in his chapter on "The Nuba Plight," none of the CPA's promises regarding the Two Areas-sharing of power and wealth, integration of the civil service and military, return of displaced persons, resolution of land disputes - has been fully implemented. Likewise, many of the Nuba's longstanding demands-self-determination, compensation for past abuses, cultural autonomy, and transitional justice-remain unfulfilled. In addition, as Tinsley points out in her chapter, "Who Will Remember the Nubans?" when South Sudan seceded and took with it much of Sudan's non-Muslim population, the Khartoum regime declared Sharia to be national law, further alienating the substantial minority of Nuba who are not Muslim.

However, rebellion has made life worse, not better, for the Nuba. Despite this reality, the SPLM-N steadfastly refuses to accept the regime's offer of negotiations on a political and security settlement for the Two Areas. Instead, the rebels demand to negotiate on nationwide political change, which the regime has made clear it will not do with them while the war continues. (In Jok's 
biased chapter, he mischaracterizes this as the rebels continuously offering negotiations, while the regime responds only with military threats.) Meanwhile, the suffering of the Nuba people continues as the SPLM-N instead pursues its national political agenda. As Kafi notes in his chapter on "The Nuba Mountains Crisis," this dynamic was further highlighted when the SPLA-N formed a military alliance with Darfur's rebels and invited them to South Kordofan, where they promptly abused the local population.

Adam's analysis of the rebels' ill-fated strategy is worth quoting at length: "The Nuba are now fighting against Khartoum, but it is not clear for what they are fighting. Certainly they are not fighting to join the south, which has betrayed them. Are they fighting for a New Sudan in the north? For an autonomous region? If the antagonism with the local pastoralist tribes continues apace, such an autonomous region would certainly be a dismal failure" (41). Adam thus implies that the Nuba might be better off negotiating with the regime on a local political settlement, which the SPLM-N refuses to do.

According to James, this realization is dawning on local populations. As she frames it, the aggrieved people of the Two Areas have two choices: embrace a nationwide military struggle to overthrow the regime in Khartoum (which could have high costs and low prospects), or "pursue local peace agreements with the government" (206). As she observes, "The government's preference is clear, and it is dividing opinion among the people of the Two Areas"(206).

If the international community really wanted to help the Nuba people, it would promote a negotiated agreement for the Two Areas, rather than acquiescing to the SPLM-N's pursuit of regime change in Khartoum, which only perpetuates suffering in the Nuba Mountains. Fostering such a soft landing, however, would require applying pressure on the SPLM-N. Regrettably, the West has done just the opposite so far, giving a pass to the rebels while exclusively pressuring the regime. As Kafi succinctly observes "The international community has ignored the abuses of the rebels and concentrated only on the abuses of the government. This encouraged the rebels to go on committing atrocities against the citizens, without any regard for innocent lives" (190).

To ensure that future intervention is more effective, it is vital to assess accurately the impact of past international responses to conflict in Sudan. Totten is likely correct that the failure to punish crimes of the 1990s in the Nuba Mountains emboldened the regime to repeat such tactics in Darfur in 2003-2004. However, the international reaction to Darfur in the mid-2000s was far more robust and did impose costs on the regime, which Tinsley fails to acknowledge and which may explain why conflict in the Two Areas since 2011 has followed a different course. In response to Darfur's atrocities, the United States declared "genocide," refused to lift sanctions as it had pledged to do, and coerced Khartoum to sign a peace deal including substantial concessions. Meanwhile the African Union and United Nations deployed tens of thousands of peacekeepers, and the ICC indicted Sudan's president and three of his subordinates. Tinsley and Totten may view such international response as inadequate, but it had a major impact on the regime's calculations.

Indeed, when I conducted interviews in Khartoum in 2013 with current and former regime officials, virtually all of them said that the government's scorched earth response to rebellion in Darfur had been a mistake, and that their president knew it, precisely because it had turned the world against the government. Since 2011, the regime again has used deadly force in the Two Areas, but it has not repeated the genocidal tactics previously employed in Darfur or the Nuba Mountains. This represents significant progress that the book fails to acknowledge. Admittedly, the current situation in the Nuba Mountains remains wretched, which is why the international community should promote both enhanced humanitarian access and a negotiated settlement. But, as those of us who study genocide know all too well, it could be a lot worse. 